Jouni Juntunen, University of Oulu, Department of Marketing, Finland Mari Juntunen, University of Oulu, Department of Marketing, Finland Vesa Autere, National Defence University, Department of Leadership and Military Pedagogy, Finland

\title{
A CASE STUDY ON THE ROLE OF THE FINNISH DEFENCE FORCES IN THE TRANSPORT SECTOR
}

\begin{abstract}
The purpose of this research is to study the significance of buyers for the transport sector, and in this particular case, the role of the Finnish Defence Forces. The theoretical model is tested with survey data $(N=460)$ collected from Finnish transport operators that do business with the Finnish Defence Forces. The data is analysed using structural equation modelling. Analyses reveal that the military forces are an important actor in the transport sector in Finland. Firstly, the military forces buy a lot of logistics services and secondly, the military forces train a significant amount of what are considered skilful truck drivers. Furthermore, seeing as there are some elements of economic protectionism in the military forces' buying behaviour, the military forces are an excellent context in which to study loyalty and partnership in business relationships. The military forces can, for instance, improve operator satisfaction with the transport sector and help domestic hauliers compete against cabotage operations, and in doing so, also improve the military forces' capability to maintain security of supply.
\end{abstract}

\section{Keywords}

Logistics, satisfaction, negotiation power, cabotage, driver training, military logistics.

\section{Introduction}

The main purpose of this research is to study the significance of the military forces in the transport sector in Finland. The goal is also to understand the military forces' role as a provider of driver training and as a buyer of logistics services. The deregulation of the international road haulage market at the beginning of the 1990s made it possible for anybody to establish their own road haulage undertaking in Finland and consequently a large number of new transport operators appeared. Similarly multiple companies that use a lot of logistics services noticed an occasion to boost their business by outsourcing 
their transportation functions to these new companies. Finland's accession to the European Union caused further notable changes in the transport sector in Finland. The border between Finland and Russia then became the eastern border of the EU, and, some years later, cabotage in international carriage within the European Union stimulated competition. If competition was hard after the deregulation, it turned out to be even harder towards the end of the decade. Hence, profit margins have remained very low during last decades. Actually, according to the Finnish Transport and Logistics organisation, SKAL, the net profits of the Finnish haulage sector were negative (-0.4 per cent) in 1999 and 2000. Furthermore, according to our data in this study, a considerable amount, over 16 per cent, of Finnish hauliers experience that cabotage operations have eroded their competitiveness.

Logistics is considered important to Finnish businesses (the number of required transportations in Finland is two times higher in relation to gross domestic product than in Europe elsewhere - www.skal.fi) as well as to the Finnish Defence Forces (Juntunen et al. 2010). Average logistics costs as a percentage of company turnover in the Finnish trade and industry sector vary from 13.3 per cent in large companies to 15.9 per cent in micro companies (Naula et al, 2006). Judging by corresponding Kearney's (2009) figures from the ELA (European Logistics Association), the share of logistics costs in the turnover of Finnish companies is approximately 37 per cent higher than in other European companies on average.

Research on the influence of the military forces on the transport sector is scarce, and, as far as the authors know, there are no previous quantitative studies on the subject. In that sense, this study is ground-breaking. We will now move on to the theoretical background, after which we will present the empirical data and statistical analysis. These will be followed by our conclusions.

\section{Theoretical background}

On a general level, it is obvious that outsourcing can have an impact on some managerial and strategic aspects of supply chains (e.g. Hilletofth and Hilmola, 2010). More specifically, according to Juntunen et al. (2010), from the Defence Forces' point of view, it is crucial to maintain an efficient 
domestic road transportation system because it is obviously impossible to outsource the Defence Forces' logistics to foreign hauliers during a crisis. Even though non-resident vehicles inside Finland can be confiscated, recruiting skilled and motivated drivers could be a problem. Hence, the relationship between the FDF and the transport sector is an extremely interesting one. In defence force logistics, the focus has to be on core tasks and core competencies (Kananen, 2009), and with supportive tasks the Defence Forces use long-term partnerships, usually with contracts of two years or longer. According to Juntunen et al. (2010), partners have to have the capability to increase readiness towards mobilization when needed, otherwise mobilization and a credible defence capability would not be possible. Therefore, in the light of previous studies, it is a given that the military have a strong influence on the transport sector.

Recruits who have gone through the FDF's military driver training programme form a crucial workforce for transport operators once they have finished their military service. To secure the availability of skilful truck drivers in a crisis situation, an 8 million euro increase was assigned to FDF drivers' training in 2007 (Hämäläinen, 2009). Six vocational schools and the Finnish Defence Forces have put forward a new cooperation model (the socalled Sokka Project) for the efficient training of drivers that would fulfil the requirements of both the FDF and the private sector (Räinä, 2009). Hence, as the FDF offer large-scale driver training because transportation is an important component of the military, hypothesis one (H1) is that the FDF's driver training explains the importance of transportation to the military forces.

To ensure the availability of transport services, the FDF should support the competitiveness of Finnish hauliers by using domestic services as much as possible (Juntunen et al. 2010). Thus, hypothesis 2 (H2) is that there is a positive relationship between the importance of transportations for the military forces and the military forces as a buyer of logistics services. In addition, the most effective way of ensuring that drivers do not forget the special skills they gained during their military services is by the military hiring their services once they work in the private sector. Hence, hypothesis three (H3) is that the FDF's driver training also explains the import that the military forces' have as a buyer of logistics services. 
Cabotage operations have become a challenge for domestic transport operators due to deregulation within the European Union. The justification for deregulation is that increasing competition lowers prices and thus benefits citizens. Hence, there are three hypotheses which theoretically draw from classic economic theory. When competition increases, strong buyers are more important for customers. This is for the reasoning behind hypothesis four (H4): the rising number of cabotage operations increases the importance of the FDF as a buyer of logistics services. Increasing competition also decreases profit margins and weakens the negotiation power of sellers. This brings us to hypothesis five (H5), an increase in cabotage operations makes the haulage business less profitable, and to hypothesis six, an increase in cabotage operations weakens the negotiating power of transport operators.

As mentioned earlier, the FDF should pay attention to domestic hauliers in order to maintain a credible defence (Juntunen et al. 2010). This justifies improve the domestic transport sector. Hypothesis eight (H8) comes from a hypothesis seven (H7): the military forces as a buyer of logistics services game theory. According to game theory, negotiation power influence to profit

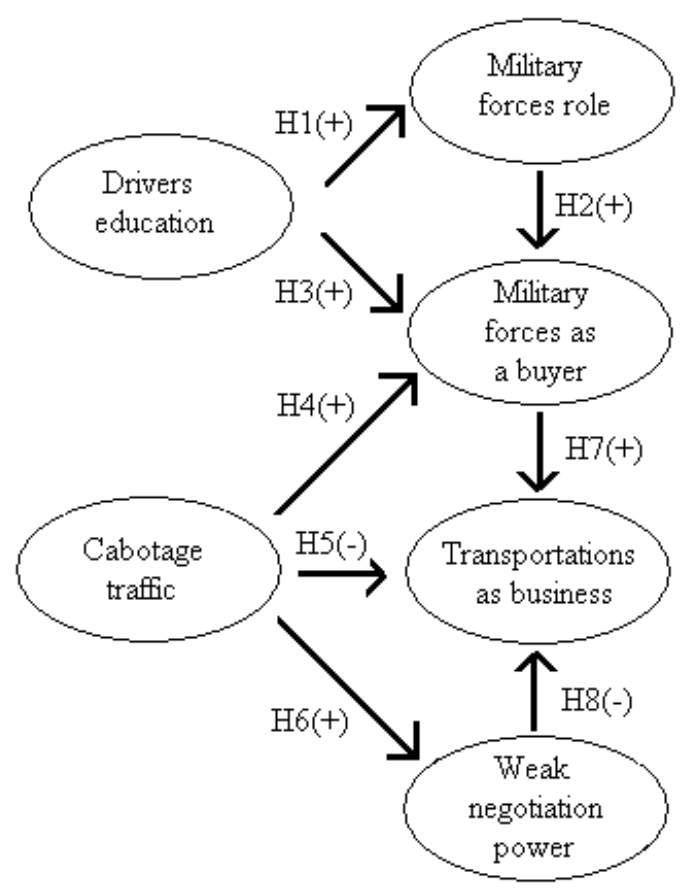

Figure 1. Theoretical model 
sharing. Hence, in this study we have assumed that weak negotiation power of the entrepreneurs in transport sector weakens whole transport sector as business (e.g. Nash, 1951; Juntunen et al. 2010). All eight hypotheses are combined into a theoretical model (figure 1) that is tested empirically with Finnish data.

\section{Empirical analyses}

The empirical data was gathered from the logistics service provider (LSP) members of the Finnish Transport and Logistics (SKAL) association in 2008 and hence the respondents were owners of small transport companies or people who are responsible for the production of transport service in larger companies. The survey was sent to all the 2,604 hauliers that belong to SKAL. In total, 460 valid responses were returned, representing a response rate of $17.7 \%$. The Internet-based Webropol online survey questionnaire was sent via e-mail to the members, and they were asked to answer the questions. Later, a reminder was sent to the members who had not yet answered the questionnaire. Non-response bias was studied by comparing different response waves (Armstrong and Overton, 1977; Lambert and Harrington, 1990) using a randomized one-way analysis of variance (ANOVA). Of the 460 companies that responded, $69.3 \%$ responded after the initial e-mail. This constitutes the first response wave. The second response wave was generated by the reminder, which is when the remaining $30.7 \%$ responded. There were no multiple statistically significant differences (using the criterion of $\mathrm{p}>$ 0.05 ) between the two groups and, therefore, it may be assumed that nonresponse bias is not a problem in this study and that the sample does represent the target group.

The questionnaire consisted of various sections designed to map outsourcingrelated logistics issues in Finland and military transport sector relationships between buyers and sellers of logistics services. It also included sections on how negotiation power, the image of the industry and contracts affect the profits of the LSPs. To give an idea of the importance of cabotage operations in Finland, according to our data, more than 16.55 per cent of respondents feel that cabotage operations have influenced market competition in the transport sector and 14.45 per cent of respondents feel that cabotage 
operations have influenced their company's operations. Operational measures are on a 7-Likert scale; respondents could either respond by choosing fully agree / fully disagree or very satisfied / very unsatisfied, depending on the question. Questions on cabotage operations were polar, i.e. yes-no questions.

Table 1. Latent variables and their operational measures

\begin{tabular}{|c|c|c|}
\hline Latent variable & $\begin{array}{l}\text { Explanation and operational measures in the } \\
\text { questionnaire. }\end{array}$ & Label \\
\hline $\begin{array}{l}\text { Military forces } \\
\text { driver education }\end{array}$ & $\begin{array}{l}\text { Refers to the military forces' status as a provider } \\
\text { of driver training. }\end{array}$ & EDUCA \\
\hline Satisfaction & $\begin{array}{l}\text { My total satisfaction toward military forces' driver } \\
\text { training. }\end{array}$ & milsati \\
\hline Workers quality & $\begin{array}{l}\text { Driver training during military service provides the } \\
\text { basics for working as a truck driver later. }\end{array}$ & workbase \\
\hline Importance & $\begin{array}{l}\text { The FDF are a very important provider of driver } \\
\text { instruction. }\end{array}$ & instruct \\
\hline $\begin{array}{l}\text { Influence of } \\
\text { cabotage }\end{array}$ & $\begin{array}{l}\text { Refers to respondents' experiences on cabotage } \\
\text { operations }\end{array}$ & CABOTAGE \\
\hline Competition & $\begin{array}{l}\text { Has the deregulation of cabotage operations } \\
\text { affected your competitiveness? }\end{array}$ & cabocomp \\
\hline Functions & $\begin{array}{l}\text { Has the deregulation of cabotage operations altered } \\
\text { the way your business operates? }\end{array}$ & cabofunc \\
\hline $\begin{array}{l}\text { Transportations' } \\
\text { importance }\end{array}$ & $\begin{array}{l}\text { Refers to the importance transportations has for } \\
\text { military }\end{array}$ & MILIMPOR \\
\hline Importance & $\begin{array}{l}\text { Transportations are the most important function in } \\
\text { military logistics. }\end{array}$ & importan \\
\hline Meaning & $\begin{array}{l}\text { We understand logistics the same way the military } \\
\text { forces do. }\end{array}$ & meaning \\
\hline $\begin{array}{l}\text { Buying } \\
\text { behaviour }\end{array}$ & $\begin{array}{l}\text { Refers to respondents' experiences of the } \\
\text { military as a buyer of logistics services }\end{array}$ & MILASBUY \\
\hline Importance & $\begin{array}{l}\text { The FDF is an important buyer of transportation } \\
\text { services. }\end{array}$ & shipper \\
\hline Cooperation & The FDF is a good partner. & partner \\
\hline $\begin{array}{l}\text { Transportaion } \\
\text { business }\end{array}$ & $\begin{array}{l}\text { Refers to respondents' experiences on } \\
\text { transportation as a business }\end{array}$ & GOODBUSS \\
\hline Profitability & Our company's profitability is good. & profit \\
\hline Satisfaction & My total satisfaction in the transport sector. & bussatis \\
\hline $\begin{array}{l}\text { Negotiation } \\
\text { power }\end{array}$ & $\begin{array}{l}\text { Refers to respondents' negative experiences with } \\
\text { regard to negotiating power }\end{array}$ & NEGOT \\
\hline Fares & $\begin{array}{l}\text { Due to tight competition in the transport sector, } \\
\text { shippers can dictate transportation fees. }\end{array}$ & fare \\
\hline Status & Transportation entrepreneurs are shippers' slaves & slave \\
\hline
\end{tabular}


The estimation was made using LISREL software (Jöreskog et al. 2000; Jöreskog et al. 1993a). The estimates were calculated using the ML (maximum likelihood) method based on a covariance matrix. The normality of the variables was studied with Prelis 2-software (Jöreskog et al. 1993b). Empirical model is presented in figure 2.

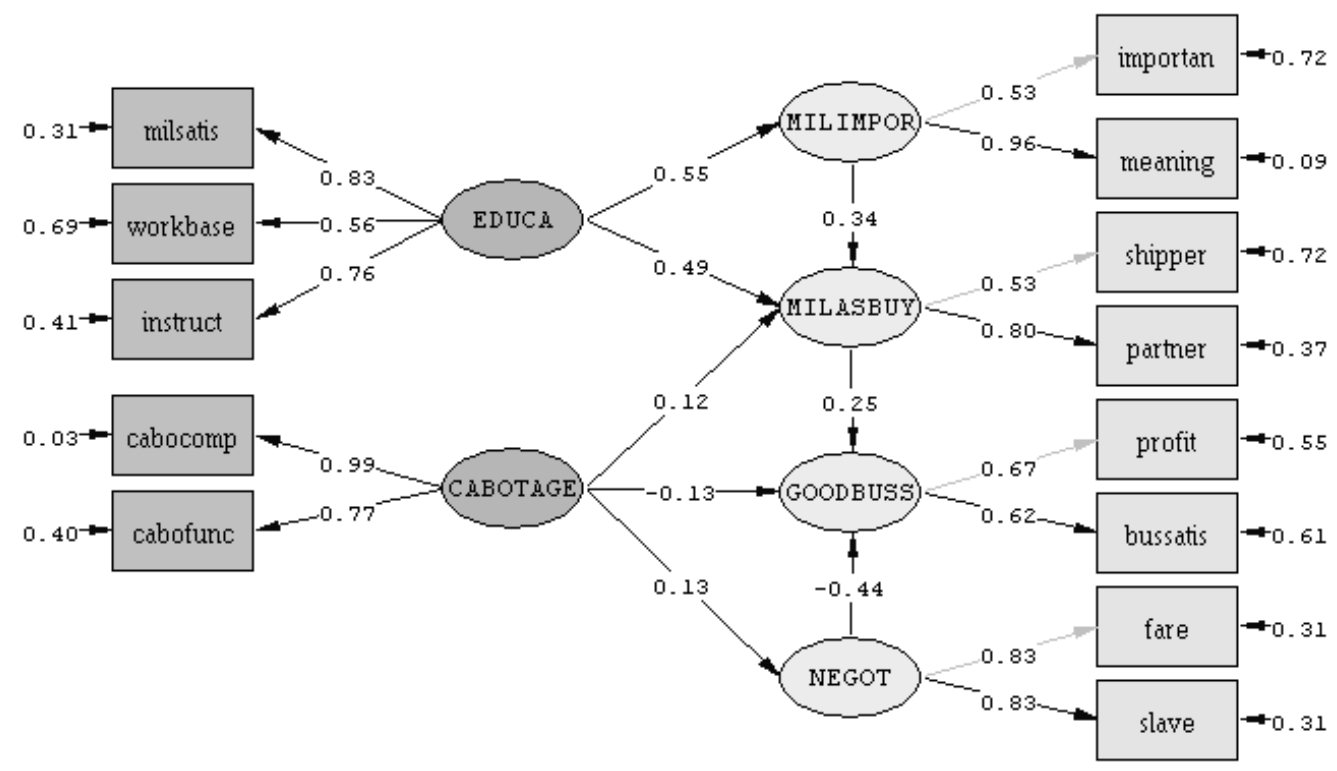

Figure 2. Empirical model

Table 2. Fit indices of the empirical models

\begin{tabular}{|l|c|}
\hline Test $\backslash$ Model & Power \\
\hline chi-square $(\mathrm{df})[\mathrm{p}$-value] & $75.38(56)[0.043]$ \\
RMSEA & 0.027 \\
CFI & 0.99 \\
GFI & 0.98 \\
NNFI & 0.99 \\
Normed chi-square & 1.346 \\
\hline
\end{tabular}

In the table 2, the Chi-square test shows a slightly inacceptable fit of the model to the data with the minimum acceptable p-value normally being 0.05 . However, the NNFI, which is suitable for a large sample, should be more than 0.90 (Hu and Bentler, 1999). As our sample size is more than double that which is recommended for the p-value, and the NNFI is very high, the model can be evaluated to be statistically significant. According to Browne 
and Cudeck (1993), an RMSEA value below 0.05 indicates a close fit of the model. Jaccard and Wan (1996) argue that the model's CFI and GFI values should be above 0.90 . Hence, based on fit indices, the model is statistically significant. Further, according to Steenkamp and van Trijp (1991), a weak condition for convergent validity is that the factor regression coefficient on a particular item is statistically significant and a stronger condition is that the factor regression coefficient is substantial. As the coefficients are substantial and statistically significant in this study, both the weak and strong conditions for convergent validity are fulfilled. Additionally, each latent variable was evaluated with their construct reliabilities and the average variance extracted (table 3).

Table 3. CR's and AVE's

\begin{tabular}{l|c|c|}
\hline Latent variable & $\begin{array}{c}\text { CR (construct } \\
\text { reliabilities) }\end{array}$ & $\begin{array}{c}\text { AVE (average } \\
\text { variance extracted) }\end{array}$ \\
\hline EDUCA & 0.77 & 0.61 \\
CABOTAGE & 0.88 & 0.61 \\
MILIMPOR & 0.73 & 0.55 \\
MILASBUY & 0.62 & 0.48 \\
GOODBUSS & 0.59 & 0.45 \\
NEGOT & 0.82 & 0.58
\end{tabular}

As most of the factors have only two measures, they are considered unidentified without a full structure, and therefore it is impossible to perform factor analyses of individual latent variables. This also weakens the usability of the traditional test values like CR and AVE and, therefore, the results should be evaluated primarily on the basis of the fit indexes of the full model and the theoretical background of these measures. The CR and AVE values also mainly support a good statistical fit of the models, whereas MILASBUY and GOODBUSS have low values. The acceptable statistical fit of the full model justifies including profits as a latent variable, even though the CR and AVE values are low. The fair response rate, which was confirmed through ANOVA analyses from the response waves, indicates that a non-response bias is not present. As all the test values of the model and the independent latent variables were at an acceptable level, it is therefore justified to argue that the validity and reliability of this study are acceptable, and that its results can be generalised. 


\section{Conclusion}

Our analysis reveals that while the bad negotiation power of entrepreneurs weakens their satisfaction with the transport sector, the FDF as a buyer of transport services off-balances this tendency. Cabotage operations also have the following effects: it emphasizes the importance of the military forces as a buyer of transport services; it worsens the transport operators' negotiation power and it weakens transportation as a business. From a respondent's perspective, the military forces' driver training explains how important transportation is for the FDF. In addition, there is positive relationship from importance of transportations services for FDF towards FDF's important role as a buyer of the logistics services.

Based on our analysis, it seems that the military forces are an important actor in the transport sector in Finland. The FDF has an important role in the transport sector two levels. Firstly, the military forces buy a lot of logistics services and it is to the military forces' advantage if they can use domestic transport operators. Secondly, the military forces are a very important establishment for instructing skilful drivers: they train a high percentage of their recruits in FDF maintenance for logistics purposes. These ready-trained truck drivers are a valuable work force for hauliers once they have finished their military service. The FDF have an instrumental role in generating satisfaction with the transport sector among transport operators, as they help domestic transport operators in the competition generated by cabotage operations. As the FDF have to maintain security of supply, there are some elements of protectionism - as in many other countries (Tainio et al. 2006; Liuhto, 2008) - in their buying behaviour. Hence when competition becomes harder, the significance of the FDF as a buyer of logistics services grows.

\section{References}

Armstrong, J.S. and Overton, T.S. (1977), Estimating Nonresponse Bias in Mail Surveys. Journal of Marketing Research, Vol. 14, No. 3, pp. 396-402.Balmer, J.M.T. and Gray, E.R. (1999) Corporate identity and corporate communications: creating a competitive advantage. Corporate Communications: An International Journal, 4(4): 171-176.

Browne and Cudeck (1993), Alternative ways of assessing model fit, in K. Bollen, and J.S. Long (Eds.) Testing Structural Equation Models. Sage Publications, Palm Springs.

Role of logistics outsourcing on supply chain strategy and management: Survey findings from Northern Europe

Hilletofth, P. and Hilmola, O-P. (2010) Role of logistics outsourcing on supply chain strategy and management: Survey findings from Northern Europe. Strategic Outsourcing: An International Journal, Vol. 3, No. 1, pp. $46-61$. 
Hu, L. and Bentler, P. M. (1999) Cutoff Criteria for Fit Indexes in Covariance Structure Analysis: Conventional Criteria Versus New Alternatives. Structural Equation Modeling, Vol. 6, No. 1, pp. 1-55.

Hämäläinen, Ilkka (2009). Suomen suurin autokoulu: Ruotuväki 9/2009

Jaccard, J. and Wan, C.K. (1996), Lisrel Approaches to Interaction Effect in Multiple Regression. Sage Publications, California.

Juntunen, J., Juntunen, M. and Autere, V. (2011) 'Protecting Finnish defence security: a logistics challenge', International Journal of Shipping and Transport Logistics, Vol. 3, No. 3, pp.295-311.

Jöreskog, K.G., Sörbom, D., du Toit, S. and du Toit, M. (2000) LISREL 8: New Statistical Features. SSI, Inc. Lincolnwood.

Jöreskog, K.G. and Sörbom, D. (1993a). LISREL 8: Structural Equation Modeling with the SIMPLIS Command Language. SSI, Inc. Lincolnwood.

Jöreskog, K.G. and Sörbom, D. (1993b). PRELIS 2:User's Reference Guide. SSI, Inc. Lincolnwood.

Kananen, I., Huoltovarmuuskeskus, Huoltoupseerilehti 2/2009.

Kearney A.T. /ELA (2009), Sixth European A.T. Kearney/ELA Logistics Study 2009/2009. European Logistics Association, Brussels.

Lambert, D. M. and Harrington, T. C., (1990) Measuring nonresponse bias in customer service mail surveys. Journal of Business Logistics, Vol. 11, No 2, pp. 5-25.

Liuhto, K. (2008) Genesis of economic nationalism in Russia. Electronic publications of Pan-European institute 3/2008.

Nash, J. (1951) Non-Cooperative Games. The Annals of Mathematics, $2^{\text {nd }}$ ser., 54(2), 286-295.

Naula, T., Ojala, L. and Solakivi, T. (2006) Finland State of Logistics. Publications of the Ministry of Transport and Communications 45/2006. Helsinki.

Räinä, Mikko Specialist, Defence Forces (2009) Kouvolan Ammatillinen Aikuiskoulutuskeskus Kuljetusosasto

Steenkamp, J.B. and van Trijp, H. (1991) The use of LISREL in validating marketing constructs. International Journal of Research in Marketing 8(1): 283-299.

Tainio, R., Huhtinen, A-M. and Tienari, J. (2006) Foreign Ownership and National Security: The Case of Finland, Paper presented to the $22^{\text {nd }}$ European Group for Organizational Studies (EGOS) standing working group on the Comparative Study of Economic Organizations, Bergen, Norway, July 6-8, 2006. 